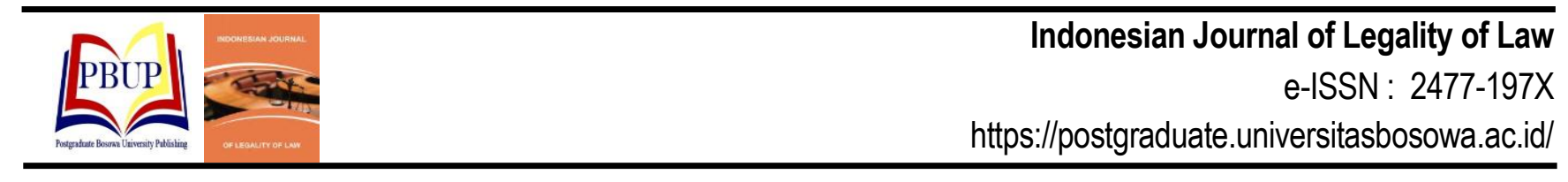

\title{
EFEKTIVITAS FUNGSI INTELIJEN KEPOLISIAN NEGARA REPUBLIK INDONESIA DALAM MEWUJUDKAN KEAMANAN DAN KETERTIBAN MASYARAKAT DI WILAYAH HUKUM POLRES MAMUJU
}

\section{The Effectiveness of the Function of Indonesian Police Force Intelligence to create security and Order in Law District of Mamuju Resort Police}

\author{
Ahmad. S ${ }^{1}$, Ruslan Renggong ${ }^{2}$, Baso Madiong ${ }^{2}$ \\ ${ }^{1}$ Kepolisian Resort Kabupaten Mamuju, Sulawesi Barat \\ ${ }^{2}$ Program Studi Ilmu Hukum Program Pascasarjana Universitas Bosowa
}

Email: ahmad@gmail.com

Diterima: 01 April 2020/Disetujui: 05 Juni 2020

\begin{abstract}
ABSTRAK
Penelitian ini bertujuan (a) untuk mengetahui Efektifitas Fungsi Intelijen Kepolisian Negara Republik Indonesia Dalam Mewujudkan Keamanan dan Ketertiban Masyarakat di Wilayah Hukum Polres Mamuju. (b) untuk mengetahui faktor-faktor yang mempengaruhi Efektifitas Fungsi Intelijen Kepolisian Negara Republik Indonesia Dalam Mewujudkan Keamanan dan Ketertiban Masyarakat di Wilayah Hukum Polres Mamuju. Metode penelitian yang digunakan adalah penelitian deskriftif yakni penelitian yang mengkaji permsalahan dengan menggunakan data perimer dan sekunder dengan cara melalui wawancara, kuesioner dan observasi langsung kelapangan serta menggunakan buku-buku, artikel melalui penelusuran internet termasuk peraturan Perundang-Undangan yang berkaitan dengan permasalahan yang dibahas dalam penelitian ini. Hasil penelitian menunjukkan bahwa Efektifitas Fungsi Intelijen Kepolisian Negara Republik Indonesia dalam Mewujudkan Keamanan dan Ketertiban Masyarakat di Wilayah Hukum Polres Mamuju dapat dikatakan cukup baik dan hal ini dapat dilihat dari Efektifitas Fungsi Intelijen Kepolisian Negara Republik Indonesia dalam Mewujudkan Keamanan dan Ketertiban Masyarakat di Wilayah Hukum Polres Mamuju melalui (1) fungsi penyelidikan, (2) fungsi pengamanan., (3) fungsi penggalangan. Sedangkan faktor yang mempengaruhi Efektifitas Fungsi Intelijen Kepolisian Negara Republik Indonesia dalam Mewujudkan Keamanan dan Ketertiban Masyarakat di Wilayah Hukum Polres Mamuju juga dapat dilihat dalam tiga hal yaitu (1) Faktor sumber daya manusia, (2) Faktor Sarana dan prasarana, (3) Faktor kondisi wilayah.
\end{abstract}

Kata Kunci: Intelijen, Polisi, Keamanan, Ketertiban, Mamuju

\section{ABSTRACT}

The research aims to know: (a) the effectiveness of the function of Indonesian Police Force Intelligence to create security and order in Law District of Mатиju Resort Police. (b) the factors that affect the effectiveness of the Function of Indonesian Police Force Intelligence to create security and order in Law District of Mamuju Resort Police. The research method used was descriptive research, a research that is used to collect primary and secondary data through interview, questionnaire and direct observation supported by the use of books and articles from the internet as well as the law and regulations in the Constitution related to the topic of this research. The result of the research shows that the effectiveness of the function of Indonesian Police Force Intelligence to create security and order in Law District of Mamuju Resort Police is quite well, which is proven by the effectiveness of the function of Indonesian Police Force Intelligence to create security and order in Law District of Mamuju Resort Police through the function of (1) Investigation, (2) Security, (3) Coordination, while the factors that affect the effectiveness of the function of Indonesian Police Force Intelligence to create security and order in Law District of Mamuju Resort Police consist of (1) Human resources, (2) Infrastructure and (3) District Environment.

Keywords: Intelligence, Police, Security, Order, Maтији

\section{PENDAHULUAN}

Salah satu modal yang tidak bisa diabaikan dan merupakan salahsatu persyaratan yang sangat dibutuhkan dalam melaksanakan kegiatan pembangunan adalah adanya situasi keamanan dan ketertiban masyarakat (kamtibmas) yang kondusif, hanya situasi Kamtibmas yang kondusiflah yang dapat mengiringi dinamika kehidupan masyarakat dengan baik, tanpa adanya keamanan dan ketertiban masyarakat niscaya pembangunan tidak akan terwujud dengan baik.

Sebagai wujud dari adanya situasi Kamtibmas yang kondusif dan dapat mendukung pembangunan adalah adanya jaminan keamanan dan kepastian hukum yang 
tinggi. Dengan adanya jaminan keamanan dan kepastian hukum yang tinggi ini, kaum investor akan datang untuk membuka berbagai kegiatannya, dan kedatangannya itu sudah pasti akan menambah denyut pembangunan bagi daerah itu serta menjadi "counter magnet" bagi warga masyarakat lainnya untuk berlomba mencari peruntungan dibidang usaha dan jasa.

Peran dan fungsi Intelijen Keamanan (Intelkam) sebagai mata dan telinga Kepolisian berkewajiban untuk melakukan identifikasi sejak dini terkait masalah, perubahan, dan perkembangannya dalam kehidupan warga negara serta mengidentifikasi ancaman, gangguan, dan/atau hambatan dalam mewujudkan keamanan dan ketertiban masyarakat (kamtibmas) (Rahmad Hutagaol: 2019)

Memasuki era globalisasi teknologi dan informatika yang ditandai dengan bersatunya negara secara global terutama melalui jaringan informasi dunia maya yang tidak bisa terbendung lagi dan keberadaannya seakan mengaburkan batas teritorial suatu negara satu dengan yang lainnya, dampak negatif bagi bangsa Indonesia adalah munculnya potensi gangguan Kamtibmas baik yang bercirikan teknologi maupun tindakan kriminalitas yang ditiru dari informasi yang terjadi di negara luar. "Imitation". Contohnya kejahatan pornograpi, pornoaksi, kejahatan susila, perjudian, penipuan dengan teknologi, kejahatan Narkoba, dan tindakan lainnya yang dapat menimbulkan gangguan Kamtibmas, dan keberadaanya dapat meresahkan masyarakat.

Teori "gunung es" tentang perkara "durk number" (Kadarmanta, 2009) tentang adanya perkara yang tidak dilaporkan, data kualitatif yang ditampilkan di Polres Mamuju, hal ini menunjukkan bahwa situasi dan kondisi di wilayah hukum Polres Mamuju belum kondusif sepenuhnya. Jika kita bandingkan Kabupaten Mamuju yang terdiri dari 11 Kecamatan, 13 Kelurahan, dan 88 Desa, jumlah penduduknya mencapai 297.096 jiwa, berarti kalau rata rata tiap 59,89 orang/penduduk terdapat satu kejahatan. Kabupaten Mamuju luas wilayah 4.999,69 $\mathrm{km}^{2}$ berarti tiap 10,08 Km terjadi satu kejahatan, sedangkan sebaran penduduk kabupaten Mamuju adalah $59 \mathrm{jiwa} / \mathrm{km}^{2}$. jika dilihat dari waktunya di Kabupaten Mamuju terdapat 0,57 kejahatan tiap jamnya, atau tiap 2 jam rata rata satu kejahatan. Bisa dibayangkan bagaimana pembangunan daerah di Kabupaten Mamuju jika gangguan keamanan relative tinggi dan cenderung meningkat dari waktu ke waktu, bagaimana ketenangan dan ketentraman masyarakat jika situasi keamnan dan ketertibannya terusi terus.

Permasalahan gangguan keamanan ini masalah yang serius dan tidak hanya terjadi di Kabupaten Mamuju saja, secara nasional mungkin dialami juga di berbagai daerah terutama kota-kota besar lainnya dan sudah berlangsung bertahun tahun kebelakang setidaknya pada tahun 2013 presiden Republik Indonesia sudah mengeluarkan instruksi presiden nomor 2 tahun 2013, kemudian disusul pada tahun 2014 yang mengeluarkan intruksinya nomor 1 tahun 2014. Instruksi Presiden No. 2 Tahun 2013 Tentang Penanganan Gangguan Keamanan Dalam Negeri substansi dapat dilihat bahwa tujuan utama dari Inpres ini adalah untuk mencapai stabilitas kondisi dalam negeri yang kondusif untuk pembangunan. Inpres ini juga dapat disebut sebagai usaha penanganan gangguan keamanan dalam negeri secara terpadu. Dalam pelaksanaan penanganan gangguan yang terpadu. Intruksi ditujukan kepada :
Permasalahannya sekarang tidak sedikit budaya masyarakat yang tidak mau untuk memperbaiki keadaan keberadaan gangguan tersebut dengan berbagai alasan, takut terlibat, tidak atau kurang kepeduliannya, tidak mau berkepanjangan yang akan mengganggu kehidupan masyarakat dan lain alasannya, akibatnya pemerintah dalam hal ini kepolisisan terkadang bekerja sendiri tanpa dukungan dari masyarakat, padahal tugas polisi terutama dalam penegakan hukum sangat memerlukan bantuan masyarakat terutama informasi yang akan membuat titik terangnya suatu permasalahan.

Demikian juga di wilayah hukum Polres Mamuju yang membawahi Kabupaten Mamuju dan Kabupaten Mamuju Tengah dalam pelaksanaan pembangunan memerlukan suatu situasi yang kondusif dalam mendukung penyelenggaraan pemerintahan guna mewujudkan pembangunan daerah yang lebih maju. Untuk mewujudkan kebutuhan tersebut diperlukan strategi yang tepat setidaknya melibatkan dukungan masyarakat banyak, masyarakat harus berani dan tidak boleh takut lagi terhadap segala bentuk munculnya gangguan keamanan dan ketertiban terutama penyampaian informasi, informasi masyarakat tersebut akan diolah untuk kemudian dijadikan bahan utama dalam setiap pengungkapan perkara. Terhadap masyarakat yang memberikan informasi pemerintah telah menjamin keamanan dengan undang-undang intelijen nomor 17 tahun 2011 tentang intelijen Negara.Dalam undang undang intelijen negara nomor 17 tahun 2011 tersebut dijelaskan dalam konsideran undang undang tersebut dijelaskan bahwa untuk terwujudnya tujuan nasional negara yang melindungi segenap bangsa Indonesia dan seluruh tumpah darah Indonesia, memajukan kesejahteraan umum, mencerdaskan kehidupan bangsa, dan ikut serta melaksanakan ketertiban dunia yang berdasarkan kemerdekaan, perdamaian abadi, dan keadilan sosial sebagaimana diamanatkan di dalam Pembukaan Undang-Undang Dasar Negara Republik Indonesia Tahun 1945, penting dilakukan deteksi dini dan peringatan dini yang mampu mendukung upaya menangkal segala bentuk ancaman yang membahayakan eksistensi dan keutuhan Negara Kesatuan Republik Indonesia; bahwa sejalan dengan perubahan, perkembangan situasi, dan kondisi lingkungan strategis, perlu melakukan deteksi dini dan peringatan dini terhadap berbagai bentuk dan sifat ancaman, baik dari dalam negeri maupun luar negeri yang bersifat kompleks serta memiliki spektrum yang sangat luas; c. bahwa untuk melakukan deteksi dini dan peringatan dini guna mencegah terjadinya pendadakan dari berbagai ancaman, diperlukan Intelijen Negara yang tangguh dan profesional, serta penguatan kerja sama dan koordinasi Intelijen Negara dengan menghormati hukum, nilai-nilai demokrasi, dan hak asasi manusia sebagaimana yang diamanatkan dalam UndangUndang Dasar Negara Republik Indonesia Tahun 1945; bahwa untuk memberikan kepastian hukum dan sesuai dengan kebutuhan hukum dalam masyarakat, penyelenggaraan Intelijen Negara sebagai lini pertama dari sistem keamanan nasional perlu diatur secara lebih komprehensif. Berbagai upaya Polri untuk melakukan pemeliharaan keamanan dan ketertiban masyarakat telah dilaksanakan, salah satunya adalah dengan mengeluarkan kebijakan berupa Peraturan Kepala Kepolisian Negara Republik Indonesia Nomor 7 tahun 2008 tentang pedoman dasar strategi dan implementasi pemolisian masyarakat. 
Peraturan Kepala Kepolisian Negara Republik Indonesia tersebut betujuan untuk dapat menanggulangi gangguan keamanan dan ketertiban masyarakat dengan melibatkan dan mengedepankan unsur masyarakat di daerah itu sendiri. Kepala Kepolisian Negara Republik Indonesia ini sangat relevan sekali dengan kebutuhan pembangunan daerah apabila diimplementasikan dengan baik, karena peraturan tersebut mengatur tentang tata cara yang efektif tentang upaya pencegahan terhadap gangguan keamanan dan ketertiban masyarakat dengan cara melibatkan semua komponen masyarakat itu sendiri. Diharapkan dari kebijakan tersebut setiap gejala atau potensi yang akan memunculkan gangguan keamanan dan ketertiban masyarakat dapat cepat terdeteksi dan masyarakat setempat bekerjasama dengan petugas kepolisian yang ditunjuk berupaya untuk menanggulanginya.

Kepolisian Resort (Polres) Mamuju merupakan salah satu jajaran terdepan Kepolisian Republik Indonesia yang berada dibawah kesatuan Polda Sulawesi Barat yang mempunyai wilayah hukum dua Kabupaten yaitu Kabupaten Mamuju dan Kabupaten Mamuju Tengah dengan jumlah penduduk menetap sebanyak 447.911 Jiwa, dengan luas daerah 8.014.08 KM2 yang terbagi dalam 16 kecamatan dengan rincian 11 Kecamatan berada di Kabupaten Mamuju dan 5 Kecamatan berada di Kabupaten Mamuju Tengah dan terdiri dari 10 Polsek. Sedangkan karakteristik daerah wilayah hukum Polres Mamuju didominasi oleh daerah pegunungan, dataran dan lautan sedangkan karakteristik penduduk bisa dikatakan Inonesia Mini karena diwilayah Hukum Polres Mamuju terdiri banyak suku, ras dan golongan sehingga dari karakteristik daerah dan penduduk inilah yang membuat wilayah hukum Polres Mamuju mempunyai trend kecenderungan meningkatnya angka gangguan keamanan dan ketertiban masyarakat dari waktu kewaktu.

Untuk itu Polres Mamuju harus dapat memberikan pelayanan keamanan dan ketertiban kepada masyarakatnya dan sangat relevan apabila dapat melaksanakan kebijakan pemolisian masyarakat mengedepankan fungsi intelijen Polri sebagai mata dan telinga pimpinan dan selalu memberikan peringatan dan deteksi dini dengan harapannya masyarakat diwilayah hukum Polres Mamuju dapat mengantisipasi setiap potensi gangguan keamanan dan ketertiban masyarakat dan dapat menanggulangi permasalahan yang berpotensi memunculkan adanya gangguan keamanan dan ketertiban masyarakat tersebut. Tujuan dari penelitian ini adalah untuk mengetahui efektifitas fungsi intelijen kepolisian negara republik indonesia dalam mewujudkan keamanan dan ketertiban masyarakat di wilayah hukum Polres Mamuju dan mengetahui faktor-faktor yang mempengaruhi efektifitas fungsi intelijen kepolisian negara republik indonesia dalam mewujudkan keamanan dan ketertiban masyarakat di wilayah hukum Polres Mamuju.

\section{METODE}

\subsection{Jenis Penelitian}

Penelitian ini merupakan tipe penelitian hukum kualitiatif. Penelitian hukum kualitatif berorientasi pada data yang didapat dari penjelasan narasumber, dokumne-dokumen dan wawancara atau bahan hukum yang berlaku dan berkaitan dengan Efektifitas Fungsi Intelijen Kepolisian Negara Republik Indonesia dalm Mewujudkan Keamanan dan Ketertiban Masyarakat di Wilayah Hukum Polres Mamuju, dengan melakukan cara wawancara dengan narasumber

\subsection{Lokasi Penelitian}

Penelitian dilakukan dalam wilayah hukum Polres Mamuju. Penentuan lokasi penelitian didasarkan atas pertimbagan bahwa dalam wilayah Hukum Polres Mamuju tersebut tersedia data yang diperlukan sebagai bahan analisis dan data tersebut diperoleh dengan mengumpulkan dokumendokumen yang berkaitan dengan Efektifitas Fungsi Intelijen Kepolisian Negara Republik Indonesia dalm Mewujudkan Keamanan dan Ketertiban Masyarakat di Wilayah Hukum Polres Mamuju

\subsection{Jenis dan Sumber Data}

Jenis data dalam penelitian ini terdiri dari data kualitatif dan data kuantitatif. Jenis data kualitatif diperlukan untuk menjelaskan berbagai hal secara naratif tentang data-data yang disajikan. Sedangkan jenis data kuantitatif untuk menghitung hasil olah data sesuai dengan interpretasinya berdasarkan hasil penelitian yang didapatkan melalui instrument penelitian.

Sumber data dalam penelitian ini adalah bersumber dari Informan, hasil obesrvasi serta dokumen-dokumen yang berkaitan dengan Fungsi Intelijen Kepolisian Negara Republik Indonesia dalm Mewujudkan Keamanan dan Ketertiban Masyarakat di Wilayah Hukum Polres Mamuju

\subsection{Informan Penelitian}

Informan pada penelitian ini adalah orang-orang yang tentang efektifitas Intelijen Kepolisian Negara Republik Indonesia dalam mewujudkan keamanan dan ketertiban masyarakat di wilayah hukum Polres Mamuju, dengan jumlah informan sebanyak 50 orang, yakni: (a) Kepala Kepolisian Resort Mamuju 1 orang, (b) Kasat Intelkam Polres Mamuju 1 orang, (c) Kepala Badan Kesbang Pol Kabupaten Mamuju 1 orang, (d) Para Kapolsek di wilayah Hukum Polres Mamuju 10 orang, (e). Para Kanit Sat Intelkam Polres Mamuju 7 orang, (f). Tokoh masyarakat dan masyarakat umum 30 orang

\subsection{Teknik Pengumpulan Data}

Penelitian ini menggukan teknik pegumpulan data, yaitu

a) Observasi partisipan, Nasution (2003) berpendapat bahwa observasi partisipan yaitu"turut sertanya seorang peneliti dengan mengambil bagian dalam kegiatan objek yang diteliti.Peneliti dengan sengaja mempertajam dan memusatkan perhatian kepada hal-hal yang diinginkan dilokasi penelitian,dan bahkan memaksakan diri untuk mengamati apa saja yang menarik perhatiannya yang dianggap berhubungan dengan objek penelitian,

b) Wawancara tak berstruktur (Unstuctured interview). Wawancara merupakan salah satu metode pengumpulan data dengan cara bertanya langsun kepada informan atau narasumber.Sedangkan yang dimaksud dengan wawacara tak berstruktur atau disebut juga wawancara terbuka menurut Esterberg yang dikutip oleh Sugiono (2010) adalah "wawancara yang bebas dimana peneliti tidak menggunakan pedoman wawancara yang telah tersusun seara sistematis dan lengkap untuk pengumpulan datanya. Pedoman wawancara yang digunakan hanya berupa garis-garis besar permasalahan yang akan ditanyakan”. Hal ini dilakukan untuk lebih memudahkan peneliti dalam mendapatkan informasi secara mendalam sehingga akan lebih memahami berbagai penomena dari objek yang diteliti. Senada dengan pendapat Susan Stainback dalam Sugiono (2010) yang mengemukakan bahwa:" Interviewing provide the researcher a mean to gain a deeper understanding of how the participant interpret a situation or phenomenon than can be gained thrimna haought observation alone". Jadi dengan wawancara ,maka peneliti akan mengetahui hal- 
hal yang lebih mendalam tentang partisipan dalam menginterprestasikan situasi dan penomena yang terjadi, dimana hal tidak bisa ditemukan melalui observasi".

c) Dokumentasi yaitu berupa foto-foto yang berfungsi untuk memperjelas uraian pembahasan bukti pendukung. Sebagaimana dikutip Sugiyono (2010) Bogdan menyatakan "Photograph provide strikingly descriptive data, are often used to understand the subjective and is product are frequeltly analyzed inductive". Hasil penelitian juga akan semakin kredibel apabila didukung oleh foto-foto,

d) Pustaka yaitu pengumpulan data dengan cara mempelajari literature yang berhubungan dengan masalah yang di teliti. Adapun metode pengumpulan data yang gunakan adalah : (a) Penelitian Kepustakaan yaitu suatu tehnik pengumpulan data dengan berpedoman pada buku-buku bacaan yang erat kaitannya Fungsi Kepolisian Negara Republik Indonesia dalm Mewujudkan Keamanan dan Ketertiban Masyarakat di Wilayah Hukum Polres Mamuju.(b) Pelelitian lapangan yaitu suatu cara penelitian yang dilaksanakan langsung kelapangan agar dapat mengetahui permasalahan yang diteliti dan untuk memudahkan dalam mengadakan penelitian langsung dilapangan tersebut maka penggunaan tehnik Wawancara, yaitu mengadakan wawancara langsung kepada Informan yang berkaitan langsung dengan Fungsi Intelijen Kepolisian Negara Republik Indonesia dalm Mewujudkan Keamanan dan Ketertiban Masyarakat di Wilayah Hukum Polres Mamuju dan Kuesioner, yaitu membagikan daftar pertanyaan kepada Informan untuk dijawab sesuai dengan Fungsi Intelijen Kepolisian Negara Republik Indonesia dalam Mewujudkan Keamanan dan Ketertiban Masyarakat di Wilayah Hukum Polres Mamuju.

\subsection{Teknik Analisis Data}

Data yang telah terkumpul akan diolah melalui teknik analisis data deskriptif kualitatif dengan tahapan-tahapan sebagai berikut : (a) Editing yaitu memeriksa seluruh kuesioner yang dikumpulkan dari informan untuk dapat memastikan kesesuaian pengisian dengan petunjuk pengisian kuesioner termasuk mengecek ulang Informan bila ada jawaban yang tidak jelas. (b) Coding yaitu memberikan kode nomor informan untuk memudahkan tabulasi data, (c) Tabulasi data yaitu mencatat semua jawaban informan mulai dari informan pertama dan terakhir.

Dengan demikian menggunakan teknik analisis data dengan bantuan tabel frekwensi dengan rumus Sugiyono (2010) sebagai berikut :

$$
\mathrm{P}=\frac{\mathrm{f}}{\mathrm{n}} \times 100 \%
$$

Keterangan :

$\mathrm{P}=$ Persentase

$\mathrm{f}=$ Frekwensi

$\mathrm{n}=$ Jumlah frekwensi dari seluruh kategori

\section{HASIL DAN PEMBAHASAN}

3.1. Efektifitas Fungsi Intelijen Kepolisian Negara Republik Indonesia dalam Mewujudkan Keamanan dan Ketertiban Masyarakat di Wilayah Hukum Polres Mamuju

Sebagaimana Peraturan Kepala Badan Intelijen Keamanan Kepolisian Negara Republik Indonesia Nomor 1
Tahun 2013 dijelaskan bahwa salah satu fungsi Intelijen Keamanan Kepolisian Negara Republik Indonesia adalah penyelidikan yakni segala usaha, pekerjaan dan kegiatan yang dilakukan secara terencana dan terarah dalam rangka mencari dan mengumpulkan bahan keterangan di bidang ideologi, politik, ekonomi, sosial budaya dan keamanan yang selanjutnya diolah dan disajikan kepada pimpinan guna menentukan kebijakan.

Sasaran penyelidikan yaitu potensi gangguan, ambang gangguan dan gangguan yang nyata dalam bentuk fenomenan, gejala dan kejadian di bidang ideologi, politik, ekonomi, sosial budaya dan keamanan yang diperkirakan akan dapat mengganggu statbilitas keamanan, ketertiban masyarakat serta kehidupan berbangsa dan bernegara.

Hasil penelitian menujukkan bahwa efektifitas fungsi intelijen kepolisian negara republik indonesia dalam mewujudkan keamanan dan ketertiban masyarakat di wilayah hukum Polres Mamuju dilihat dari fungsi penyelidikan dapat dikatakan cukup efektif. Hal ini dibuktikan dari hasil jawaban Informan melalui kuesioner dari empat opsi jawaban yang disediakan dalam pertanyaan mengenai hal tersebut, lebih banyak Informan yang memberikan jawaban sangat efektif dan cukup efektif dibandingkan Informan yang memberikan jawaban kurang efektif dam tidak efektif sebagaimana dalam tabel di bawah ini

Tabel 1

Efektifitas Fungsi Intelijen Kepolisian Negara Republik Indonesia dalam Mewujudkan Keamanan dan Ketertiban Masyarakat menurut Fungsi Penyelidikan.

\begin{tabular}{cccc}
\hline No & Kategori Jawaban & $\begin{array}{c}\text { Frekuensi } \\
\text { (orang) }\end{array}$ & $\begin{array}{c}\text { Persentase } \\
(\boldsymbol{\%})\end{array}$ \\
\hline 1. & Sangat Efektif & 11 & 22 \\
2. & Cukup Efektif & 30 & 60 \\
3. & Kurang Efektif & 6 & 12 \\
4. & Tidak Efektif & 3 & 6 \\
\hline & Jumlah & 50 & 100 \\
\hline
\end{tabular}

Sumber Data : Kuesioner diolah, November 2019

Hasil informan dalam Tabel 1. di atas, didapatkan gambaran bahwa Efektifitas Fungsi Intelijen Kepolisian Negara Republik Indonesia dalam Mewujudkan Keamanan dan Ketertiban Masyarakat di Wilayah Hukum Polres Mamuju dilihat dari fungsi penyelidikan dapat dikategorikan sudah cukup efektif. Hal tersebut dibuktikan dari 50 orang Informan yang memberikan jawabannya, 11 orang dengan persentase mencapai $22 \%$ Informan yang memberikan jawaban sangat efektif, 30 orang dengan persentase mencapai $60 \%$ Informan yang memberikan jawaban cukup efektif, 6 orang dengan persentase mencapai 12\% Informan yang memberikan jawaban kurang efektif dan 3 orang dengan persentase mencapai 6\% Informan yang memberikan jawaban tidak efektif.

Berdasarkan uraian di atas, bahwa efektifitas fungsi intelijen kepolisian negara republik indonesia dalam mewujudkan keamanan dan ketertiban masyarakat di wilayah hukum Polres Mamuju dilihat dari fungsi penyelidikan masuk kategori cukup efektif. Dalam Peraturan Badan Inelijen Keamanan Kepolisian Negara Republik Indonesia Nomor 2 Tahun 2013 tentang Pengamanan Intelijen Kepolisian Negara Republik Indonesia menjelaskan bahwa Pengamanan merupakan salah satu kegiatan intelijen dalam rangka menjamin terpeliharanya kondisi keamanan yang kondusif dan dinamis dengan cara memperkecil dan meniadakan 
kesempatan dan peluang bagi pihak lain/ oposisi yang akan mengganggu stabilitas ketertiban atau dapat menghambat kelangsungan kehidupan bermasyarakat, berbangsa, dan bernegara di dalam Negara Kesatuan Republik Indonesia.

Untuk mencapai keberhasilan penyelenggaraan tugas pengamanan Intelijen Kepolisian secara optimal, maka perlu didukung oleh personel yang profesional, sarana dan prasarana serta dukungan anggaran yang memadai, aspek legalitas serta ketentuan ketentuan/petunjuk yang menyangkut sistem, metode dan teknik yang berlaku bagi penyelenggaraan kegiatan Pengamanan Intelijen Kepolisian.

Pengamanan Intelijen adalah segala usaha, pekerjaan, kegiatan yang dilakukan secara terencana, terarah dan tertutup untuk mencegah, dan menangkal serta menemukan jejak, menggagalkan usaha-usaha, pekerjaan dan kegiatan pihak lain/oposisi dalam melakukan sabotase, spionase/pencurian bahan keterangan dan yang dapat mengancam perikehidupan masyarakat dan pelaksanaan pembangunan nasional. Pengamanan intelijen kepolisian adalah pengamanan yang dilakukan secara tertutup oleh organ intelijen kepolisian.

Hasil penelitian diketahui bahwa efektifitas fungsi intelijen kepolisian negara republik indonesia dalam mewujudkan keamanan dan ketertiban masyarakat di wilayah hukum Polres Mamuju dilihat dari fungsi pengamanan dapat dikatakan cukup efektif. Hal ini dibuktikan dari hasil jawaban Informan melalui kuesioner dari lima opsi jawaban yang disediakan dalam pertanyaan mengenai hal tersebut, lebih banyak Informan yang memberikan jawaban sangat efektif dan cukup efektif dibandingkan Informan yang memberikan jawaban kurang efektif, tidak efektif dan sangat tidak efektif.

Untuk lebih jelasnya berikut jawaban Informan tentang Efektifitas Fungsi Intelijen Kepolisian Negara Republik Indonesia dalam Mewujudkan Keamanan dan Ketertiban Masyarakat di Wilayah Hukum Polres Mamuju dilihat dari fungsi pengamanan dalam tabel di bawah ini.

\section{Tabel 2}

Efektifitas Fungsi Intelijen Kepolisian Negara Republik Indonesia dalam Mewujudkan Keamanan dan Ketertiban Masyarakat Menurut Fungsi Pengamanan.

\begin{tabular}{cccc}
\hline No & Kategori Jawaban & $\begin{array}{c}\text { Frekuensi } \\
\text { (orang) }\end{array}$ & $\begin{array}{c}\text { Persentase } \\
(\mathbf{\%})\end{array}$ \\
\hline 1. & Sangat Efektif & 10 & 20 \\
2. & Cukup Efektif & 29 & 58 \\
3. & Kurang Efektif & 7 & 14 \\
4. & Tidak Efektif & 4 & 8 \\
\hline & Jumlah & 50 & 100 \\
\hline
\end{tabular}

Sumber Data : Kuesioner diolah, November 2019

Tabel 2. di atas, didapatkan gambaran bahwa efektifitas fungsi intelijen kepolisian negara republik indonesia dalam mewujudkan keamanan dan ketertiban masyarakat di wilayah hukum Polres Mamuju dilihat dari fungsi pengamanan dapat dikategorikan cukup efektif. Hal tersebut dibuktikan dari 50 orang Informan yang memberikan jawabannya, 10 orang dengan persentase mencapai $20 \%$ Informan yang memberikan jawaban sangat efektif, 29 orang dengan persentase mencapai $58 \%$ Informan yang memberikan jawaban cukup efektif, 7 orang dengan persentase mencapai 14\% Informan yang memberikan jawaban kurang efektif dan 4 orang dengan persentase mencapai $8 \%$ Informan yang memberikan jawaban tidak efektif.

Berdasarkan uraian di atas, menujukkan bahwa efektifitas fungsi intelijen kepolisian negara republik indonesia dalam mewujudkan keamanan dan ketertiban masyarakat di wilayah Hukum Polres Mamuju dilihat dari fungsi penyelidikan masuk kategori cukup efektif.

Penggalangan intelijen adalah semua usaha, pekerjaan dan kegiatan yang dilakukan secara berencana, terarah oleh sarana Intelijen untuk membuat, menciptakan, mengubah suatu kondisi dalam masyarakat sehingga mencapai keadaan yang menguntungkan terhadap pelaksanaan tugas pokok Kepolisian Negara Republik Indonesia.

Kegiatan Penggalangan Intelijen adalah semua usaha, pekerjaan, kegiatan dan tindakan yang dilakukan secara berencana dan terarah terhadap sasaran-sasaran individu sebagai informal leader maupun terhadap kelompok masyarakat baik kelompok formal maupun kelompok informal yang berpotensi terhadap keamanan dan ketertiban masyarakat guna mendukung terciptanya keamanan dan ketertiban masyarakat.

Berdasarkan hasil penelitian menunjukkan bahwa efektifitas fungsi intelijen kepolisian negara republik indonesia dalam mewujudkan keamanan dan ketertiban masyarakat di wilayah hukum Polres Mamuju dilihat dari fungsi penggalangan dapat dikatakan cukup efektif.

Hal ini dibuktikan dari hasil jawaban Informan melalui kuesioner dari lima opsi jawaban yang disediakan dalam pertanyaan mengenai hal tersebut, lebih banyak Informan yang memberikan jawaban sangat efektif dan cukup efektif dibandingkan Informan yang memberikan jawaban kurang efektif dan tidak efektif.

Untuk lebih jelasnya berikut jawaban Informan tentang Efektifitas Fungsi Intelijen Kepolisian Negara Republik Indonesia dalam Mewujudkan Keamanan dan Ketertiban Masyarakat di Wilayah Hukum Polres Mamuju dilihat dari fungsi penggalangan dalam tabel di bawah ini.

\section{Tabel 3}

Efektifitas Fungsi Intelijen Kepolisian Negara Republik Indonesia dalam Mewujudkan Keamanan dan Ketertiban Masyarakat Menurut Fungsi Penggalangan.

\begin{tabular}{cccc}
\hline No & Kategori Jawaban & $\begin{array}{c}\text { Frekuensi } \\
\text { (orang) }\end{array}$ & $\begin{array}{c}\text { Persentase } \\
(\boldsymbol{\%})\end{array}$ \\
\hline 1. & Sangat Efektif & 9 & 18 \\
2. & Cukup Efektif & 30 & 60 \\
3. & Kurang Efektif & 8 & 16 \\
4. & Tidak Efektif & 3 & 6 \\
\hline \multicolumn{4}{c}{ Jumber Data : Kuesioner diolah, November 2019 }
\end{tabular}

Tabel 3. di atas, didapatkan gambaran bahwa efektifitas fungsi intelijen kepolisian negara republik indonesia dalam mewujudkan keamanan dan ketertiban masyarakat di wilayah hukum Polres Mamuju dilihat dari fungsi penggalangan dapat dikategorikan cukup efektif. Hal tersebut dibuktikan dari 50 orang Informan yang memberikan jawabannya, 9 orang dengan persentase mencapai $18 \%$ Informan yang memberikan jawaban sangat efektif, 30 orang dengan persentase mencapai $60 \%$ Informan yang memberikan jawaban cukup efektif, 8 orang dengan persentase mencapai 16\% Informan yang memberikan jawaban kurang efektif dan 4 orang dengan persentase mencapai $6 \%$ Informan yang memberikan jawaban tidak efektif.

Berdasarkan uraian di atas, menujukkan bahwa efektifitas fungsi intelijen kepolisian negara republik indonesia dalam mewujudkan keamanan dan ketertiban masyarakat di wilayah hukum Polres Mamuju dilihat dari fungsi penggalangan masuk kategori cukup efektif. 
3.2. Faktor-Faktor yang Mempengaruhi Efektifitas Fungsi Intelijen Kepolisian Negara Republik Indonesia dalam Mewujudkan Keamanan dan Ketertiban Masyarakat di Wilayah Hukum Polres Mamuju

Hasil penelitian menunjukkan sumber daya manusia cukup berpengaruh terhadap efektifitas fungsi intelijen kepolisian negara republik indonesia dalam mewujudkan keamanan dan ketertiban masyarakat di wilayah hukum Polres Mamuju. Hal ini dibuktikan dari hasil jawaban Informan melalui kuesioner dari lima opsi jawaban yang disediakan dalam pertanyaan mengenai hal tersebut, lebih banyak Informan yang memberikan jawaban sangat berpengaruh dan cukup berpengaruh dibandingkan Informan yang memberikan jawaban kurang berpengaruh dan tidak berpengaruh sebagaimana dalam tabel di bawah ini.

\section{Tabel 4}

Pengaruh Sumber Daya Manusia terhadap Efektifitas Fungsi Intelijen Kepolisian Negara Republik Indonesia dalam Mewujudkan Keamanan dan Ketertiban Masyarakat di Wilayah Hukum Polres Mamuju.

\begin{tabular}{cccc}
\hline No & Kategori Jawaban & $\begin{array}{c}\text { Frekuensi } \\
\text { (orang) }\end{array}$ & $\begin{array}{c}\text { Persentase } \\
(\mathbf{\%})\end{array}$ \\
\hline 1. & Sangat Berpengaruh & 10 & 20 \\
2. & Cukup Berpengaruh & 31 & 62 \\
3. & Kurang Berpengaruh & 7 & 14 \\
4. & Tidak Berpengaruh & 2 & 4 \\
\hline & Jumlah & 50 & 100 \\
\hline
\end{tabular}

Sumber Data : Kuesioner diolah, November 2019

Tabel 4. di atas, didapatkan gambaran bahwa sumber daya manusia cukup berpengaruh terhadap efektifitas fungsi intelijen kepolisian negara republik indonesia dalam mewujudkan keamanan dan ketertiban masyarakat di wilayah hukum Polres Mamuju. Hal tersebut dibuktikan dari 50 orang Informan yang memberikan jawabannya, 10 orang dengan persentase mencapai $20 \%$ Informan yang memberikan jawaban sangat berpengaruh, 31 orang dengan persentase mencapai $62 \%$ Informan yang memberikan jawaban cukup berpengaruh, 7 orang dengan persentase mencapai 14\% Informan yang memberikan jawaban kurang berpengaruh dan 2 orang dengan persentase mencapai $4 \%$ Informan yang memberikan jawaban tidak berpengaruh.

Berdasarkan uraian di atas, menujukkan bahwa sumber daya manusia cukup berpengaruh terhadap efektifitas fungsi intelijen kepolisian negara republik indonesia dalam mewujudkan keamanan dan ketertiban masyarakat di wilayah hukum Polres Mamuju. Berdasarkan hasil penelitian bahwa sumber daya manusia cukup berpengaruh terhadap efektifitas fungsi intelijen kepolisian negara republik indonesia dalam mewujudkan keamanan dan ketertiban masyarakat di wilayah hukum Polres Mamuju. Hal ini dibuktikan dari hasil jawaban Informan melalui kuesioner dari lima opsi jawaban yang disediakan dalam pertanyaan mengenai hal tersebut, lebih banyak Informan yang memberikan jawaban sangat berpengaruh dan cukup berpengaruh dibandingkan Informan yang memberikan jawaban kurang berpengaruh dan tidak berpengaruh.

Untuk lebih jelasnya berikut jawaban Informan tentang Pengaruh sarana dan prasarana terhadap efektifitas fungsi intelijen kepolisian negara republik indonesia dalam mewujudkan keamanan dan ketertiban masyarakat di wilayah hukum Polres Mamuju dalam tabel di bawah ini.

Tabel 5

Pengaruh Sarana dan Prasarana terhadap Efektifitas Fungsi Intelijen Kepolisian Negara Republik Indonesia dalam Mewujudkan Keamanan dan Ketertiban Masyarakat di Wilayah Hukum Polres Mamuju.

\begin{tabular}{cccc}
\hline No & Kategori Jawaban & $\begin{array}{c}\text { Frekuensi } \\
\text { (orang) }\end{array}$ & $\begin{array}{c}\text { Persentase } \\
(\mathbf{\%})\end{array}$ \\
\hline 1. & Sangat Berpengaruh & 13 & 26 \\
2. & Cukup Berpengaruh & 32 & 64 \\
3. & Kurang Berpengaruh & 4 & 8 \\
4. & Tidak Berpengaruh & 1 & 2 \\
\hline & Jumlah & 50 & 100 \\
\hline
\end{tabular}

Sumber Data : Kuesioner diolah, November 2019

Tabel 5. di atas, didapatkan gambaran bahwa sarana dan prasarana cukup berpengaruh terhadap efektifitas fungsi intelijen kepolisian negara republik indonesia dalam mewujudkan keamanan dan ketertiban masyarakat di wilayah hukum Polres Mamuju. Hal tersebut dibuktikan dari 50 orang Informan yang memberikan jawabannya, 13 orang dengan persentase mencapai $26 \%$ Informan yang memberikan jawaban sangat berpengaruh, 32 orang dengan persentase mencapai $64 \%$ Informan yang memberikan jawaban cukup berpengaruh, 4 orang dengan persentase mencapai $8 \%$ Informan yang memberikan jawaban kurang berpengaruh dan 1 orang dengan persentase mencapai 2\% Informan yang memberikan jawaban tidak berpengaruh.

Berdasarkan uraian di atas, menujukkan bahwa sarana dan prasarana cukup berpengaruh terhadap efektifitas fungsi intelijen kepolisian negara republik indonesia dalam mewujudkan keamanan dan ketertiban masyarakat di wilayah hukum Polres Mamuju. Kondisi wilayah adalah salah satu hal yang sangat menentukan keberhasilan dalam melaksanakan tugas dan tanggung jawab seseorang dalam satu lembaga pemerintahan atau organisasi. Kondisi wilayah Mamuju sebagai wilayah Hukum Polres Mamuju, merupakan kondisi wiayah yang masuk kategori sulit, karena wilayah Kabupaten Mamuju memiliki wilayah pesisir, pulau-pulau dan pegunungan yang akses terhadap wilayah tersebut sebagian besar masih sulit dijangkau baik melalui transportasi darat maupun melalui jaringan telpon yang masih sangat terbatas. Di Kabupaten Mamuju terdapat wilayah pegunungan yang sangat sulit yakni Kecamatan Kalumpang yang mana wilayah ini sangat sulit dijangkau baik transportasi darat seperti kendaraan roda 4 maupun jaringan telpon yang belum ada, sehingga dibutuhkan waktu khusus untuk menjangkaunya. Demikian pula wilayah Kecamatan Balak-Balakang yang mana wilayah ini hanya bisa dilalui dengan transportasi laut dan juga jaringan telpon yang belum ada. Semua ini memberikan pengertian bahwa kondisi wilayah Mamuju masih sangat sulit dijangkau.

Berdasarkan hasil penelitian diketahui bahwa kondisi wilayah cukup berpengaruh terhadap efektifitas fungsi intelijen kepolisian negara republik indonesia dalam mewujudkan keamanan dan ketertiban masyarakat di wilayah hukum Polres Mamuju. Hal ini dibuktikan dari hasil jawaban Informan melalui kuesioner dari lima opsi jawaban yang disediakan dalam pertanyaan mengenai hal tersebut, lebih banyak Informan yang memberikan jawaban sangat berpengaruh dan cukup berpengaruh dibandingkan Informan 
yang memberikan jawaban kurang berpengaruh dan tidak berpengaruh sebagaimana dalam tabel di bawah ini.

\section{Tabel 6}

Pengaruh Kondisi Wilayah terhadap Efektifitas Fungsi

Intelijen Kepolisian Negara Republik Indonesia dalam

Mewujudkan Keamanan dan Ketertiban Masyarakat di Wilayah Hukum Polres Mamuju.

\begin{tabular}{cccc}
\hline No & Kategori Jawaban & $\begin{array}{c}\text { Frekuensi } \\
\text { (orang) }\end{array}$ & $\begin{array}{c}\text { Persentase } \\
(\mathbf{\%})\end{array}$ \\
\hline 1. & Sangat Berpengaruh & 10 & 20 \\
2. & Cukup Berpengaruh & 29 & 58 \\
3. & Kurang Berpengaruh & 8 & 16 \\
4. & Tidak Berpengaruh & 3 & 6 \\
\hline & Jumlah & 50 & 100 \\
\hline
\end{tabular}

Sumber Data : Kuesioner diolah, November 2019

Tabel 6. di atas, didapatkan gambaran bahwa kondisi wilayah cukup berpengaruh terhadap Efektifitas Fungsi Intelijen Kepolisian Negara Republik Indonesia dalam Mewujudkan Keamanan dan Ketertiban Masyarakat di Wilayah Hukum Polres Mamuju. Hal tersebut dibuktikan dari 50 orang Informan yang memberikan jawabannya, 10 orang dengan persentase mencapai $20 \%$ Informan yang memberikan jawaban sangat berpengaruh, 29 orang dengan persentase mencapai 58\% Informan yang memberikan jawaban cukup berpengaruh, 8 orang dengan persentase mencapai $16 \%$ Informan yang memberikan jawaban kurang berpengaruh dan 3 orang dengan persentase mencapai $6 \%$ Informan yang memberikan jawaban tidak berpengaruh. Berdasarkan uraian di atas, bahwa kondisi wilayah cukup berpengaruh terhadap Efektifitas Fungsi Intelijen Kepolisian Negara Republik Indonesia dalam Mewujudkan Keamanan dan Ketertiban Masyarakat di Wilayah Hukum Polres Mamuju.

\section{KESIMPULAN}

Hasil penelitian dan pembahasan menujukkan bahwa efektifitas fungsi intelijen kepolisian negara republik indonesia dalam mewujudkan keamanan dan ketertiban masyarakat di wilayah hukum Polres Mamuju dapat dikatakan cukup baik dan hal ini dapat dilihat dari melalui fungsi penyelidikan, fungsi pengamanan., fungsi penggalangan. Ketiga hal di atas, nilai cukup efektif dengan persentase mencapai 59,3\%. sedangkan faktor yang mempengaruhi dapat dilihat dalam tiga hal yaitu faktor sumber daya manusia, faktor sarana dan prasarana, faktor kondisi wilayah yang juga rata-rata informan memberikan jawaban cukup berpengaruh dengan persentase mencapai $61,3 \%$.

\section{DAFTAR PUSTAKA}

Instruksi Presiden Nomor 2 Tahun 2013 tentang Penanganan Gangguan Keamanan dalam Negeri

Instruksi Presiden Nomor 1 Tahun 2014 tentang Penanganan Gangguan Keamanan dalam Negeri

Kadarmanta, 2009, Bahaya Narkoba di Kalangan Remaja, RinekaCipta

Nasution, 2003, Pengantar Penelitian Ilmiah, Rineka Cipta Bandung.

Peraturan Kepala Kepolisian Negara Republik Indonesia Nomor 7 Tahun 2008 Tentang Pedoman Dasar Strategi Dan Implementasi Pemolisian Masyarakat Dalam Penyelenggaraan Tugas Polri
Peraturan Kepala Kepolisian Negara Republik Indonesia Nomor 22 Tahun 2010 Tentang Susunan dan Tata Kerja Organisasi pada Tingkat Kepolisan Daerah

Peraturan Kepala Kepolisian Negara Republik Indonesia Nomor 23 Tahun 2010 Tentang Susunan dan Tata Kerja Organisasi pada Tingkat Kepolisan Resor dan Kepolisian Sektor

Peraturan Kepala Badan Intelijen Keamanan Kepolisian Negara Republik Indonesia Nomor 1 Tahun 2013 tentang Penyelidikan

Peraturan Kepala Badan Intelijen Keamanan Kepolisian Negara Republik Indonesia Nomor 2 Tahun 2013 tentang Pengamanan

Rahmad Hutagaol. (2019). Peran Satuan Intelkam Dalam Mencegah Paham Radikal di Masyarakat Melalui Deradikalisasi (Studi Pada Satuan Intelkam Polres Deli Serdang). Jurnal Hukum Kaidah: Media Komunikasi dan Informasi Hukum dan Masyarakat, Universitas Islam Sumatera Utara, 19(2), hlm. 188.

Sugiyono, 2010, Teknik Penulisan Karya Ilmiah, PT Mandar Maju, Jakarta

Undang-Undang Dasar Negara Republik Indonesia Tahun 1945

Undang-Undang Nomor 2 Tahun 2002 tentang Kepolisian Negara Republik Indonesia

Undang-Undang Nomor 17 Tahun 2011 tentang Intelijen Negara

Undang-Undang Nomor 32 tahun 2004 tentang Pemerintah Daerah 